\title{
ВИКОРИСТАННЯ ЦИФРОВИХ ІНСТРУМЕНТІВ ДЛЯ ЗАБЕЗПЕЧЕННЯ ЕФЕКТИВНОГО ДИСТАНЦЙНОГО Й ЗМШШАНОГО НАВЧАННЯ В КРИЗОВИХ УМОВАХ
}

\author{
Андрій Беспалий \\ викладач інформаційних технологій, \\ спеціаліст другої кваліфікаційної категорії, \\ Комунальний заклад «Покровський педагогічний фахових коледж» \\ м. Покровськ, Україна \\ ORCID ID 0000-0002-3438-7106 \\ web.gynabes@gmail.com
}

\section{Любов Дегтярьова}

викладач математичних дисциплін, спеціаліст першої кваліфікаційної категорії,

Комунальний заклад «Покровський педагогічний фахових коледж»

м. Покровськ, Україна

ORCID ID 0000-0001-5074-6589

lubaxa8484@gmail.com

\section{Ольга Жмуренко}

викладач математичних дисциплін, голова циклової комісії математичних дисциплін, спеціаліст другої кваліфікаційної категорії,

Комунальний заклад «Покровський педагогічний фахових коледж»

м. Покровськ, Україна

ORCID ID 0000-0002-2478-7413

zfantastikaz@gmail.com

Анотація. Статтю присвячено актуальній проблемі організації дистанційного та змішаного навчання в кризових умовах: розкрито сутність понять «дистанційне навчання» та «змішане навчання», охарактеризовано цифрові інструменти для здійснення ефективного онлайн-навчання та переваги дистанційних технологій; визначено ролі викладачів і студентів у дистанційному навчанні. Узагальнення досвіду здійснювалося на базі Комунального закладу «Покровський педагогічний фаховий коледж». У статті обгрунтовано необхідність застосування різних цифрових інструментів при здійсненні дистанційного та змішаного навчання для забезпечення кращого засвоєння знань здобувачами освіти та з метою сприяння формуванню їх професійної компетентності.

Ключові слова: дистанційне навчання; змішане навчання; Moodle; Zoom; Nearpod; YouTube; онлайн-курси.

Постановка проблеми в загальному вигляді. Актуальність проблеми викликана загальною кризою в освіті, яка виникла через пандемію та призвела до суттєвих змін у освітній сфері протягом 2020-2021 навчального року в усьому

() ДВНЗ «Донбаський державний педагогічний університет» 


\section{А. БЕСПАЛИЙ, Л. ДЕГТЯРЬОВА, О. ЖМУРЕНКО \\ Використання цифрових інструментів для забезпечення ефективного дистанційного й змішаного навчання в кризових умовах}

світі. Проводити уроки віддалено, не бачити учнів, не мати можливостей пояснити особисто й допомогти в момент виникнення проблеми - ще кілька місяців тому вчителі не могли й уявити такого стану речей у своїй роботі. Але пандемія внесла несподівані корективи і змусила всіх терміново опановувати цифрові інструменти й нові педагогічні підходи та методики. Вимушене дистанційне навчання стало викликом для всіх учасників освітнього процесу: викладачів, здобувачів освіти та батьків. Дистанційна форма навчання передбачає доступ до інтернету, технічне забезпечення (комп'ютер, планшет, смартфон тощо) в усіх учасників освітнього процесу, а також достатній рівень володіння викладачами різноманітними технологіями дистанційного навчання.

Організувати якісне навчання 3 використанням цифрових технологій, надихати й мотивувати учнів, давати раду технічним проблемам виявилось зовсім не просто.

3 огляду на це досить актуальною є проблема організації дистанційного та змішаного навчання в кризових умовах, адже правильно організоване навчання сприяє підвищенню якості знань та рівня інтелектуально-творчого розвитку здобувачів освіти.

Аналіз останніх досліджень і публікацій. Аналіз джерел 3 проблеми організації дистанційного навчання засвідчує значний інтерес вітчизняних i зарубіжних науковців до питань розвитку сучасної освіти. На даний момент досліджено напрями підвищення ефективності навчання 3 використанням інформаційних технологій (В. Биков Р. Гуревич, М. Кадемія, Д. Опеншоу, Н. Тверезовська, І. Хорев, М. Жалдак, Ю. Жук); концептуальні педагогічні положення про дистанційне навчання (О. Андрєєв, Г. Козлакова, І. Козубовська, В. Олійник, С. Полат, П. Стефаненко, А. Хуторський); дидактичні властивості комп'ютерних засобів (С. Полат); педагогічні підходи до комп'ютеризації навчального процесу (Б. Гершунський, Є. Машбиць, І. Підласий); теорію і практику модульного навчання (В. Огнев’юк, О. Фурман); теорію і практику особистісно-орієнтованого навчання (I. Бех, С. Подмазін, І. Якиманський, В. Рибалка); методи творчого навчання за допомогою телекомунікаційних засобів (Г. Андріанова, А. Кудін, А. Хуторський). Незважаючи на велику кількість досліджень, сучасна дистанційна освіта в Україні поки що нагадує традиційні форми заочного навчання, не розкриває всіх можливостей використання принципово нових форм i методів навчання i тому потребує особливої уваги та дослідження. 

А. БЕСПАЛИЙ, Л. ДЕГТЯРЬОВА, О. ЖМУРЕНКО
Використання цифрових інструментів для забезпечення
ефективного дистанційного й змішаного навчання в кризових умовах

Формулювання цілей статті (постановка завдання). Мета статті полягає в теоретичному обгрунтуванні сутності дистанційного та змішаного навчання $\mathrm{i}$ ефективності цифрових інструментів, що забезпечують успішність процесу здійснення такого навчання в кризових умовах.

Результати дослідження. Одним із пріоритетних напрямів програми модернізації загальноосвітньої і вищої школи визнане дистанційне навчання. У сучасних умовах існує нагальна потреба отримання освіти дистанційно, що викликана необхідністю навчатися в кризових умовах - умовах пандемії. Таку можливість надає дистанційне навчання, що здійснюється завдяки інформаційно-освітнім технологіям і системам комунікації (Graham, 2005).

Як визначено наказом Міністерства освіти i науки України від 25.04.2013 р. №466 «Про затвердження Положення про дистанційне навчання», зареєстрованим у Міністерстві юстиції України 30 квітня 2013 р. за № 703/23235, дистанційне навчання - це індивідуалізований процес набуття знань, умінь, навичок і способів пізнавальної діяльності людини, що відбувається в основному за опосередкованої взаємодії віддалених один від одного учасників навчального процесу в спеціалізованому середовищі, яке функціонує на базі сучасних психолого-педагогічних та інформаційно-комунікаційних технологій.

Основні принципи дистанційного навчання - це встановлення інтерактивного спілкування між студентом та викладачем без забезпечення їх безпосередньої зустрічі та самостійне опанування певного масиву знань i навичок за обраним курсом при використанні певних інформаційних технологій (Siemens, Gašević, \& Dawson2015).

В Україні поняття дистанційного навчання належить до тих дидактичних понять, місце яких серед дидактичних категорій не є суворо визначеним. Цьому сприяла відсутність донедавна єдиної концепції дистанційного навчання. Нині існують різні погляди на дистанційне навчання: від його абсолютизації як нової універсальної форми навчання, спроможної змінити традиційну, до технології комплектування засобів і методів передачі навчальної інформації. Сучасні комп'ютерні телекомунікації здатні забезпечити передачу знань і доступ до різноманітної навчальної інформації іноді ефективніше, ніж традиційні засоби навчання.

Експериментально підтверджено, що якість і структура навчальних курсів, так само як і якість викладання при дистанційному навчанні, часто набагато краща, ніж при традиційних формах навчання. Нові електронні технології, такі як електронні дошки оголошень, мультимедійний гіпертекст, доступні через глобальну мережу Інтернет, не тільки можуть забезпечити активне залучення 

А. БЕСПАЛИЙ, Л. ДЕГТЯРЬОВА, О. ЖМУРЕНКО
Використання цифрових інструментів для забезпечення
ефективного дистанційного й змішаного навчання в кризових умовах

студента в навчальний процес, а й дозволяють керувати цим процесом на відміну від більшості традиційних навчальних середовищ. Інтеграція звуку, рухомого зображення і тексту створює нове, надзвичайно багате за своїми можливостями навчальне середовище, 3 розвитком якого збільшиться і ступінь залучення студента до процесу навчання. Інтерактивні можливості програм і систем доставки інформації, що використовуються в системі дистанційного навчання, дозволяють налагодити і навіть стимулювати зворотний зв’язок, забезпечити діалог і постійну підтримку, які не можливі в більшості традиційних систем навчання (Бугайчук, 2011).

Отже, дистанційне навчання - це форма навчання 3 використанням комп'ютерних і телекомунікаційних технологій, що забезпечують інтерактивну взаємодію викладачів та студентів на різних етапах навчання та стимулюють самостійну роботу з матеріалами інформаційної мережі. Це ідеальне рішення для тих, хто надає перевагу сучасним інформаційним технологіям в освіті й цінує свій час. Дистанційне навчання дає студентам можливість цілодобового доступу до навчальних матеріалів, забезпечує постійну підтримку й консультації викладачів та методистів, відеолекції в режимі online, віртуальні тренажери та інші технологічні рішення для забезпечення ефективного процесу навчання.

Наразі дистанційна форма навчання демонструє свої переваги перед іншими формами навчання завдяки своїй значно вищій інформативності, доступності та економічній ефективності. Вона також потребує менше часу та енергії для засвоєння знань, є значно мобільнішою та комфортнішою, ніж інші форми навчання. Саме цими та іншими причинами зумовлюється експансія дистанційної форми навчання в усьому світі, а групове навчання в аудиторіях та читальних залах поступово втрачає свої позиції.

До переваг дистанційної освіти можна віднести наступне: можливість індивідуалізації навчання, вибір бажаного темпу та швидкості навчання, висока якість контролю знань за допомогою модульної системи навчання, ефективне тестування.

На даний час відбувається процес упровадження нових педагогічних технологій у систему дистанційного навчання. Механізмом проведення цих перетворень у нашій країні стає реалізація концепції змішаного навчання (blended learning) - це відносно новий підхід у навчальному процесі середньої освіти, що створює сприятливе освітнє інформаційне середовище, систему комунікацій, які надають необхідну навчальну інформацію. 


\section{А. БЕСПАЛИЙ, Л. ДЕГТЯРЬОВА, О. ЖМУРЕНКО \\ Використання цифрових інструментів для забезпечення ефективного дистанційного й змішаного навчання в кризових умовах}

Наразі у вітчизняній та зарубіжній термінології існує багато різних підходів щодо визначення поняття змішаного навчання. Змішане навчання як інструмент модернізації сучасної освіти на практиці представляється у створенні нових педагогічних методик, що грунтуються на інтеграції традиційних підходів організації навчального процесу, при якому здійснюється передача знань та технології електронного навчання. При змішаному навчанні від 30\% до 80\% академічного навчального процесу переноситься 3 аудиторій у віртуальний простір Інтернету, де здобувачі освіти можуть самі обирати шлях, час і темп отримання знань.

На думку К. Куна (2006), метою змішаного навчання є прагнення об'єднати переваги очного навчання та електронних ресурсів. Д. Пейнтер визначає змішане навчання як об'єднання традиційних формальних засобів навчання: роботу в аудиторіях, вивчення теоретичного матеріалу, із неформальними, наприклад, із обговоренням за допомогою електронної пошти та Інтернет-конференцій. Р. Шанк розуміє під змішаним навчанням використання електронного та аудиторного навчання. С. Моебз і С. Вейбелзах (2006) визначають змішане навчання як «поєднання дистанційного i традиційного спілкування в інтегрованій навчальній діяльності». На думку Грехема (2005), змішане навчання - це підхід, який інтегрує традиційне навчання та комп'ютерно опосередковане навчання в педагогічному середовищі.

За визначенням вітчизняних авторів С. Березенської, В. Кухаренка (2016), змішане навчання - це цілеспрямований процес здобування знань, умінь та навичок в умовах інтеграції аудиторної та позааудиторної навчальної діяльності суб'єктів освітнього процесу на основі використання і взаємного доповнення технологій традиційного, електронного, дистанційного та мобільного навчання при наявності самоконтролю студента за часом, місцем, маршрутами та темпом навчання.

Таким чином, blended learning - це освітня концепція, у рамках якої здобувач освіти отримує знання і самостійно (онлайн), і очно (із викладачем). Цей підхід у навчанні дає можливість контролювати час, місце, темп і шлях вивчення матеріалу. За своєю суттю blended learning - це змішання традиційної класно-урочної системи та сучасної цифрової освіти. Основними елементами моделі змішаного навчання є лекційні та практичні заняття, семінари, практичні завдання (самостійні та контрольні роботи, реферати, доклади та ін.), навчальні матеріали (підручники, методичні посібники), онлайн-спілкування (чат, форум, e-mail), індивідуальні та групові онлайн-проєкти, віртуальна класна кімната, аудіо- та відеолекції, анімація та симуляції .

() ДВНЗ «Донбаський державний педагогічний університет» 
У Комунальному закладі «Покровський педагогічний фаховий коледж» створені всі умови для здійснення ефективного дистанційного та змішаного навчання. Якісне навчання організовується за допомогою сучасного апаратного та програмного забезпечення й різноманітних цифрових інструментів.

Для дистанційного навчання потрібно впровадити зручну та просту ВКЗсистему, що дозволить не тільки проводити дистанційні лекції у форматі фільму, а й організувати взаємодію між учасниками освітнього процесу. Потрібно організувати мобільність викладача, щоб він міг швидко виконати всі ті операції, які робив в умовах очного навчання. Виходячи з цього, просто сучасного ПК не достатньо, потрібен потужній комп'ютер із ресурсами, що дозволять одночасно вести трансляцію та працювати в декількох додатках, а також стабільне та швидке Інтернет-з'єднання, мінімум 100 Мб/сек. Велике значення має передача зображення та робочий простір викладача, тому ефективно використовувати 2-3 монітори діагоналлю від 21 до 32 дюймів.

Засобом для ефективної передачі інформації адресатам у контексті навчання може виступати графічний планшет, що збільшить можливості роботи викладача біля дошки. Документ-камера оптимально швидко допоможе продемонструвати необхідний навчальний матеріал 3 великої кількості друкованих джерел або транслювати робочу поверхню стола з приладдям для дослідів. Не останнє місце посідає відеокамера, оскільки саме якість зображення дозволяє утримувати увагу здобувачів освіти і створювати ефект присутності викладача поряд, а не просто демонструє відображення його на екрані. Для якісної передачі відеозображення потрібна камера 3 якісною лінзою та роздільною здатністю FULL HD.

Для якісного сприймання та усвідомлення навчального матеріалу студентам необхідно використовувати телефон, планшет або графічний планшет, комп'ютер або ноутбук одночасно, щоб отримати знання в повному обсязі. При використанні вищезазначеного обладнання вибір конкретного програмного забезпечення є другорядним і залежить тільки від зручності його використання та досвіду учасників освітнього процесу.

У період організації дистанційного та змішаного навчання під час пандемії заклади освіти самостійно обирали різноманітні платформи для здійснення освітнього процесу. Однією з таких платформ є система керування навчанням Moodle. 


\section{А. БЕСПАЛИЙ, Л. ДЕГТЯРЬОВА, О. ЖМУРЕНКО \\ Використання цифрових інструментів для забезпечення ефективного дистанційного й змішаного навчання в кризових умовах}

Moodle - найпоширеніша на сьогодні система електронного навчання не тільки в Україні, а й за кордоном. Цей інтерфейс перекладений 82 мовами та використовується в 50 тисячах організацій із 200 країн світу (Бугайчук, 2011).

Середовище Moodle призначене для створення онлайн-курсів i має оптимальний набір ресурсних можливостей для реалізації змішаного навчання. Для вивчення дисциплін пропонується традиційні очні заняття поєднувати 3 самостійною роботою в дистанційному курсі. Такий підхід до опанування змісту дисципліни дозволяє вирішити проблему з відвідуванням занять (пропущений матеріал здобувачі освіти можуть засвоїти через онлайн-курси), реалізовувати принцип випереджаючого навчання (можливість ознайомитись із новим матеріалом до заняття), розвивати інформаційно-комунікаційну компетентність здобувачів (Швецова \& Бондаренко, 2019, с. 79).

Використання Moodle як системи управління навчанням дає змогу чітко структурувати та наочно представити навчальний матеріал, робить електронні засоби навчання більш доступними; забезпечує створення індивідуальної траєкторії навчання, вибору темпу, часу й місця аудиторної та позааудиторної роботи; уможливлює перевірку знань і контроль успішності тих, хто навчається; зберігає портфоліо виконаних робіт студентів, систематизує отримані оцінки в журналі навчальних досягнень; сприяє організації інформаційної взаємодії суб'єктів навчального процесу, а також проходженню курсу декількома групами одночасно (Михайлова, 2012, с. 14-15). До того ж, віртуальне навчальне середовище Moodle уможливлює поєднання традиційної (face-to-face) i дистанційної (distributed learning system) систем навчання відповідно до типу закладу освіти, цілей, завдань, етапу навчання, а також рівня підготовки здобувачів, а його структурні компоненти: мотиваційний, програмнометодичний, інформаційно-діяльнісний, комунікаційний, контрольнооцінювальний і технологічний - дають змогу створити необхідні умови для організації навчальної діяльності студентів.

При цьому мотивачійний компонент сприяе підвищенню навчальної мотивації і рівня відповідальності здобувачів за результати самостійної навчальної роботи; програмно-методичний передбачає інформування здобувачів про цілі, завдання, структуру і зміст самостійної навчальної діяльності, терміни виконання самостійної роботи, ознайомлення з різними стратегіями навчання, а також робочими програмами та графіком освітнього процесу тощо, інформаційно-діяльнісний має на меті організацію такої самостійної навчальної діяльності здобувачів, у процесі якої в них мають формуватися необхідні професійні компетентності. комунікаційний забезпечує комунікацію всіх 

А. БЕСПАЛИЙ, Л. ДЕГТЯРЬОВА, О. ЖМУРЕНКО
Використання цифрових інструментів для забезпечення ефективного дистанційного й змішаного навчання в кризових умовах

учасників процесу навчання; контрольно-оцінювальний - прогнозує здійснення контролю і самоконтролю в процесі самостійної роботи здобувачів, а також отримання інформації про інтенсивність роботи кожного студента, статистичні дані щодо результатів навчальної діяльності, сприяє підвищенню рівня рефлексії в студентів, формує в них готовність до здійснення самооцінювання i самоконтролю; технологічний забезпечує технічну підтримку організації самостійної навчальної діяльності студентів (Михайлова, 2012, с. 16).

Отже, віртуальне навчальне середовище Moodle, поза іншим, становить систему управління навчанням і дає змогу проєктувати на його основі електронні навчальні курси.

Із 2020 року в Комунальному закладі «Покровський педагогічний фаховий коледж» у зв'язку із введенням карантинних заходів постало питання організації змішаного та дистанційного навчання. Вибір дистанційного середовища Moodle в якості засобу для формування професійної компетентності здобувачів пояснюється не лише тим, що ця платформа визнана найпопулярнішою в освітніх системах багатьох країн світу, а й тому, що вона безкоштовна, надійна в експлуатації, модульна, безпечна, зручна у використанні та управлінні освітнім процесом.

Використовуючи платформу Moodle в освітньому процесі, здобувач під керівництвом викладача опрацьовує на заняттях навчальний матеріал, що подається в різному вигляді (текстовому, графічному, анімаційному, гіпертекстовому); виконує необхідні навчальні завдання; складає заліки у вигляді тестування тощо. Moodle надає доступ до численних ресурсів, студенти отримують нові можливості для вивчення дисципліни: можна не лише в будьякий час переглядати необхідний матеріал у режимі онлайн, а й пройти тестування, перевірити свої знання 3 предмету, ознайомитися 3 додатковими джерелами. Система дистанційного навчання в змішаній моделі дозволяє також використовувати різні додаткові елементи при вивченні дисциплін: аудіо- i відеозаписи, анімації та симуляції.

Можна виділити корисні можливості, які надає користувачам середовище Moodle: усі ресурси зібрані в єдине ціле, що забезпечує ефективне розв'язання навчальних задач; викладач постійно перебуває на зв'язку зі здобувачами та контролює процес навчання; студенти мають можливість об'єднуватися в групи за ролями для здійснення певних дій (Unified Modeling Language, б.д.).

Переваги використання зовнішньої навчальної платформи Moodle при викладанні дисциплін полягають у можливості змістовного наповнення та 
коригування навчального матеріалу безпосередньо викладачем з урахуванням останніх технічних новинок, оновлення змісту лекцій, практичних занять, тестових завдань, методичних вказівок та інших навчально-методичних матеріалів.

Викладач, за необхідності, може відокремити певну інформацію від загального доступу та надати ключі до навчальних матеріалів студентам певних курсів та спеціальностей. Це забезпечує авторську безпеку лектору.

Платформа надає можливість широкоформатного спілкування в системі «викладач - група студентів» (проведення інтернет-екскурсій, інтернетконференцій) і «викладач - студент» на рівні електронної пошти та онлайнспілкування у віртуальному навчальному середовищі.

У межах віртуального навчального середовища Moodle електронні курси можуть мати різні формати, проте найбільш зручним є так званий форматструктура, що передбачає поділ курсу на розділи (модулі), що розміщуються між блоками (Рис. 1), є автономними організаційно-методичними одиницями змісту навчальної дисципліни (Михайлова, 2012, с. 33).
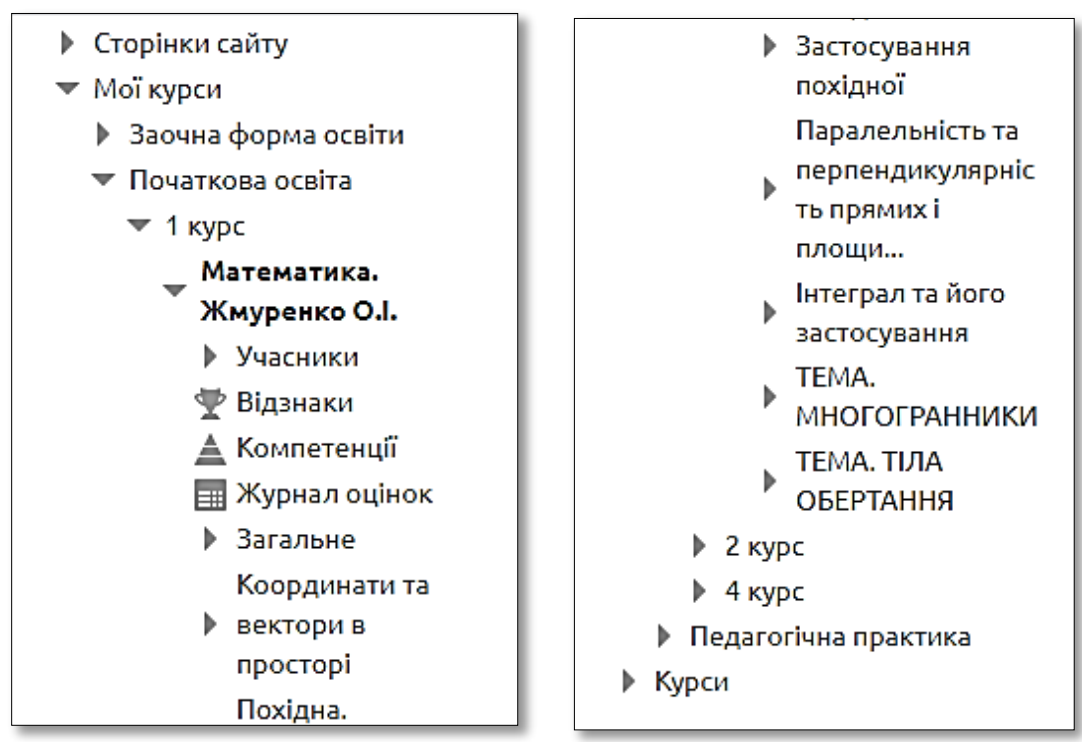

Рис. 1. Фрагмент структури дистаниійного освітнього курсу Математика у віртуальному навчальному середовищі Moоdle

Блоки також $є$ компонентами курсу і можуть бути групою посилань або інших засобів роботи з курсом, об'єднаних за загальними ознаками (Рис. 2). 
А. БЕСПАЛИЙ, Л. ДЕГТЯРЬОВА, О. ЖМУРЕНКО

Використання цифрових інструментів для забезпечення

ефективного дистанційного й змішаного навчання в кризових умовах
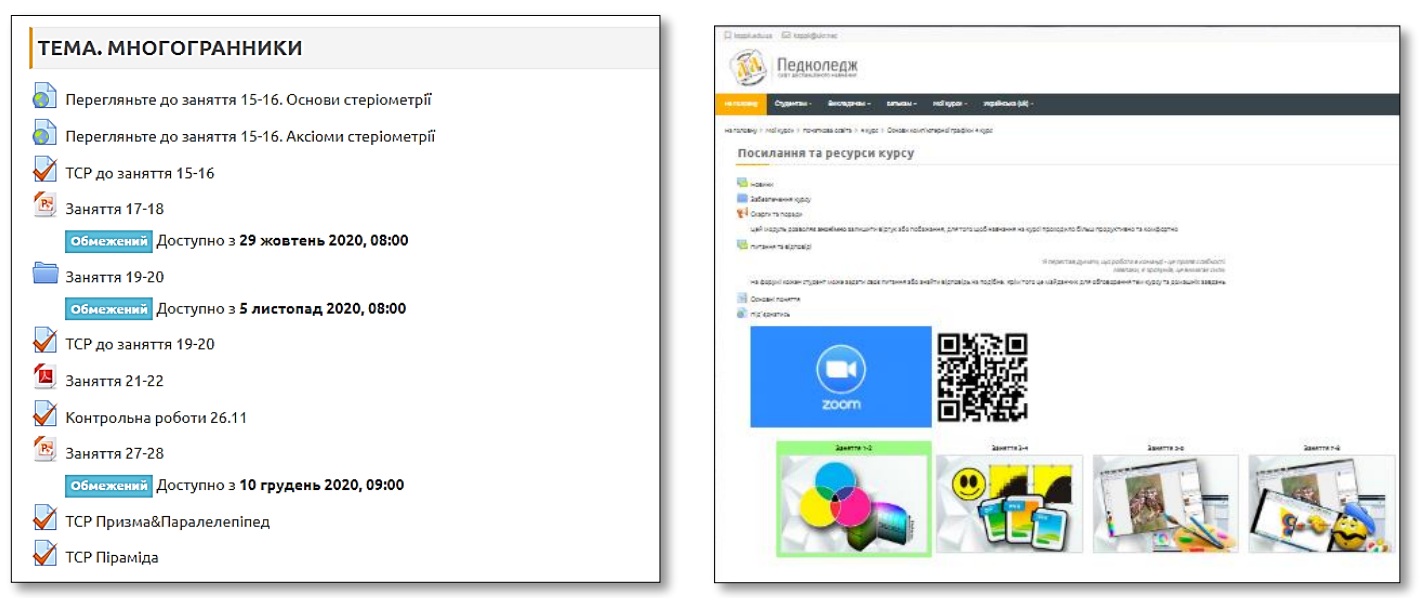

Рис. 2. Приклад блоків дистанційного освітнього курсу Математика та Основи комп 'ютерної графіки у віртуальному навчальному середовищі Moоdle

Зміст кожного модуля в Moodle може бути представлений такими стандартними навчальними елементами (що встановлені за замовчуванням):

- навчальні ресурси - теоретичні матеріали, які викладач розміщує в розділах курсу, можуть бути у вигляді файлів, що завантажуються на сервер системи Moodle або посилань на зовнішні сайти. Система Moodle уможливлює використання різних форматів електронних документів: текстова сторінка (створення сторінки 3 текстом із використанням різних видів форматування: автоформат, HTML-формат, текстовий формат, Markdown-формат), пояснення (текст та зображення, що відображаються безпосередньо на головній сторінці курсу серед інших ресурсів та елементів курсу, наприклад, для назви модуля або розділу), веб-сторінка (полегшує створення окремої веб-сторінки в межах Moodle, особливо в разі використання вбудованого в Moodle HTML-редактора, така сторінка зберігається в базі даних, а не у файлі), посилання на файл або вебсторінку (створення посилання на будь-яку веб-сторінку або файл у мережі Інтернет чи завантажену в курс, прості html-сторінки відображаються такими, якими $\epsilon$, тоді як файли з мультимедійних форматів можуть вбудовуватися в текстову сторінку, наприклад, МР3-файли відображаються 3 використанням вбудованого програвача тощо), посилання на каталог (відображення вмісту цілого каталогу та його підкастів, дає можливість студентам завантажувати й переглядати будь-які файли, що є там);

- діяльнісні елементи (на відміну від ресурсів передбачають активну участь студентів), до яких належать завдання (постановка завдання викладачем), чат (синхронний обмін повідомленнями в реальному часі), форум (обговорення різних тем, на відміну від чату, вхід у форум можливий протягом декількох днів 
у будь-який час), глосарій (укладання термінів із їх визначенням), база даних (укладання бази структурованих записів у відповідності 3 попередньо визначеною тематикою), wiki (колективне редагування текстів), тести різних форматів (так/ні, множинного вибору, на відповідність, коротка і розгорнута відповідь) (Бугайчук, 2011, с. 34).

Система Moodle надає багато можливостей в організації повноцінного освітнього процесу, включаючи засоби навчання, систему контролю й оцінювання навчальної діяльності студентів та інші необхідні складові системи електронного навчання. Вона цілком відповідає вимогам, що висуваються до подібних систем, і це робить їі ефективним засобом для використання у закладах освіти.

В умовах переходу на формат онлайн-навчання виникла потреба використання засобів з функціями групових чатів, дзвінків та конференцій. Одним із інструментів, найбільш пристосованих для навчання та зручних у використанні, є програма Zoom.

Zoom - це сервіс для організації онлайн-занять і веб-семінарів (вебінарів). Zoom забезпечує проведення необмеженої кількості конференцій, зустрічей, вебінарів.

Можливості Zoom - це проведення онлайн-занять із відео високої якості та можливістю участі до 100 користувачів (у безкоштовній версії заняття може тривати не довше 40 хвилин); функція демонстрації матеріалів на робочому столі ПК під час занять і семінарів; планування занять заздалегідь і можливість запрошувати учасників; запис занять за участі студентів; організація загальних і приватних чатів для листування та обміну матеріалами.

Сервіс дозволяє не тільки слухати, а й брати активну участь в онлайнзустрічі. Під час конференції адміністратор може призначити співорганізатора, у якого будуть такі ж можливості, як і у ведучого зустрічі - вмикати і вимикати мікрофон в окремих учасників, ділитися трансляцією екрану. Крім того, Zoom пропонує стабільне з'єднання, відсутність високих вимог до оперативної пам'яті ПК та Інтернету. Користувач платформи отримує доступ до безкоштовної підтримки 24/7.

Справжнім помічником став сервіс Zoom при проведенні дистанційних занять. Ця сучасна програма дозволила не просто проводити онлайн-заняття, а робити це ефективно. При проведенні онлайн-занять у Zoom викладачі застосовували різноманітні Інтернет-сервіси для створення інтерактивних дидактичних матеріалів та миттєвої преревірки знань: Kahoot, LearningApps, Wordwall, Quizalize. 
Інтернет-сервіси для створення дидактичних матеріалів - це нова можливість для викладачів, крок у смарт-світ. Наприклад, багатофункціональний інструмент WordWall застосовувався викладачами для створення власних наборів інтерактивних вправ і матеріалів: вікторин, змагань, лабіринтів, тестів, ігор, які можна використати при проведенні онлайн-занять в Zoom (Рис. 3).
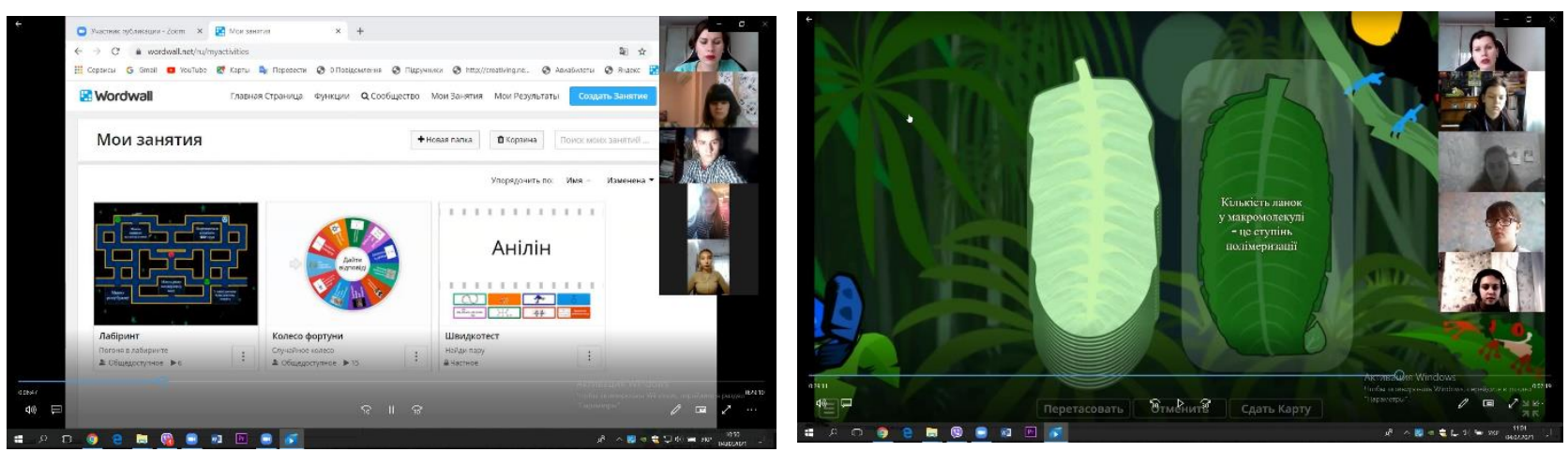

Рис. 3. Скріншоти з відкритих занять, проведених у Zоот.

По-перше, під час таких занять відбувається інтерактивна співпраця зі студентами. По-друге, усі розробки можна зробити публічними й ділитися ними 3 колегами. По-третє, усі створені завдання Wordwall можна розмістити на іншому веб-сайті, використовуючи фрагмент HTML-коду. Це працює так само, як функція вставки відео з YouTube, що дає змогу додавати навчальні завдання на сайті викладача.

Можна зазначити, що сервіс Zoom - це провідний сервіс із низкою спеціальних функцій для забезпечення якісного дистанційного навчання. Це просте, зрозуміле, сучасне знаряддя, що допомагає викладачам відповідати вимогам сучасної діджиталізації.

У сучасних здобувачів освіти ключовими засобами взаємодії 3 навколишнім світом $є$ гаджети та девайси (спілкування у соціальних мережах, перегляд фільмів, прослуховування музики тощо). Залучення новітніх інтернеттехнологій в освітній процес, дозволяє ефективно взаємодіяти зі здобувачами синхронно або асинхронно у зручному для них форматі. 3 огляду на це, викладачі Покровського педагогічного фахового коледжу при організації дистанційного та змішаного навчання активно використовують онлайн-платформу Nearpod, що дозволяє зробити процес навчання цікавим, насиченим, наочним, пізнавальним, інтерактивним і особистісно-орієнтованим.

Nearpod - це сучасна онлайн-платформа, що дозволяє створювати навчальні матеріали, демонструвати їх здобувачам на заняттях і відстежувати 


\section{А. БЕСПАЛИЙ, Л. ДЕГТЯРЬОВА, О. ЖМУРЕНКО \\ Використання цифрових інструментів для забезпечення \\ ефективного дистанційного й змішаного навчання в кризових умовах}

результат опанування теми. Зручний безкоштовний онлайн-інструмент, завдяки якому можна створювати заняття, наповнені різноманітними активними формами. На платформі не потрібно формувати групи й реєструвати учасників: щоб долучитися до заняття, здобувачам достатньо скористатися посиланням.

Nearpod надає можливість працювати за допомогою швидкого інтерактивного зв'язку на інтерактивній дошці, де здобувач залишає свою відповідь.

Дана онлайн-платформа надає два режими доступу: для здобувачів і для викладачів. Режим викладача дозволяє створювати навчальні презентації, наповнювати їх необхідним контентом і ділитися ними зі здобувачами. Продукт, що створює викладач, може нести в собі інформативну, навчальну функцію для демонстрації нового матеріалу або контролюючу, а може поєднувати всі відразу. Це залежить від того, які цілі переслідує викладач і які інструменти обирає для подачі/збору інформації у своїй презентації.

Безкоштовна версія 3 мінімальним набором необхідних інструментів (платна версія має значно розширений функціонал), дозволяє завантажувати зображення, графіки, діаграми, аудіо- та відеофайли, створювати опитування, вікторини, тести та голосування, $\epsilon$ можливість використання відкритих питань для того, щоб здобувачі могли самовиражатися, а також присутній інструмент «дошка», де можна графічно щось зобразити (Прилуцкая, 2016).

Онлайн-платформа Nearpod надає можливості використовувати більше відкритих питань у презентації, що спонукають здобувачів глибше вивчати тему й висловлювати свою думку. Викладач може створити такі налаштування або додавати завдання 3 інших серверів, щоб під час заняття здобувачі могли додавати свій контент: зображення, посилання на сайти. Це може бути приводом для насичених дискусій і засобом самовираження. Адже одна з головних переваг використання інтерактивних презентацій полягає в тому, що висловитися публічно й бути почутим може кожен.

На відміну від популярних інструментів для інтерактивних презентацій, Nearpod не залежить від інших додатків. Брати участь у сесіях можна 3 будьякого пристрою і з будь-якої платформи: IOS, Android, Windows Phone. Ще одна корисна функція - домашнє завдання. Працювати з презентацією в такому режимі здобувачі можуть самостійно, не підключаючись до загальної сесії.

Під час запуску цієї програми можна обрати один із п'яти варіантів роботи:

- моя бібліотека - доступ і запуск занять, презентацій, вікторин, що створені на комп'ютері чи запозичені з колекції додатку;

- дослідження - можливість знайти готові матеріали з різних освітніх

(ㄷ ДВНЗ «Донбаський державний педагогічний університет» 
галузей;

- приєднатися - використання Nearpod для роботи здобувачів;

- create - конструктор занять, презентацій, вікторин;

- reports - звіти, де викладач може побачити результати роботи здобувачів.

Усі ці можливості дозволяють зробити заняття по-справжньому інтерактивним, адже кожен здобувач захоплено виконує завдання за допомогою свого мобільного, а викладач при цьому відразу бачить результат і може приділити кожному належну увагу.

Платформа Nearpod стане в нагоді при організації ефективної онлайнкомунікації під час дистанційної роботи та під час заняття в режимі реального часу. Цікавий функціонал програми дозволить перетворити звичні презентації в гейміфіковані інтерактиви та справжні комп’ютерні ігри.

Висновки 3 дослідження і перспективи подальших розвідок у цьому напрямі. Підсумовуючи вищенаведене, слід зазначити, що перехід на дистанційне навчання, зумовлений пандемією, став неочікуваним i доволі серйозним випробуванням для всіх учасників освітнього процесу. Після тимчасової розгубленості всім довелося прийняти цей виклик та швидко адаптуватися до нових реалій, а питання розвитку дистанційної освіти набуло неабиякої актуальності.

I хоча дистанційне навчання не є заміною очного та ніколи не планувалося на довгострокову перспективу, воно може стати ефективним інструментом не тільки під час карантину. Упровадження дистанційних технологій у навчальний процес спрямоване на глибше розуміння навчального матеріалу; формування таких компетенцій як комунікативні (безпосереднє спілкування за допомогою засобів мережі), інформаційні (пошук інформації з різних джерел та можливість ii критичного осмислення), самоосвіти (уміння навчатися самостійно). Як показує практика, якщо студент не навчиться самостійно приймати рішення, визначати зміст своєї навчальної діяльності та знаходити засоби іiі реалізації, він не зможе якісно оволодіти тією чи іншою дисципліною. Окрім того, дистанційне навчання виконує й виховну функцію - сприяє формуванню провідних якостей особистості: активності, самостійності, самовдосконалення, творчості.

Система дистанційної освіти може й повинна зайняти своє місце в системі освіти, оскільки при грамотній ii організації, правильному виборі цифрових інструментів, вона може забезпечити якісну освіту, що відповідає вимогам сучасного суспільства сьогодні.

Професіоналізм педагога: теоретичні й методичні аспекти. Методичні матеріали до проєкту «Цифровий освітній простір: українсько-польський досвід». - Слов’янськ, 2021. 


\title{
СПИСОК ВИКОРИСТАНИХ ДЖЕРЕЛ
}

1. Graham, C. R. (2005). Blended learning system: Definition, current trends and future direction. In: Bonk, C.J., Graham, C.R. (eds.) Handbook of Blended Learning: Global Perspectives, Local Designs, pp.3-21. Pfeiffer, San Francisco.

2. Moebs, S. \& Weibelzahl, S. (2006). Towards a good mix in blended learning for small and medium sized enterprises - Outline of a Delphi Study. Proceedings of the Workshop on Blended Learning and SMEs held in conjuction with the 1stEuropean Conference on Technology Enhancing Learning. Crete, Greece, 1-6.

3. Siemens, G., Gašević, D., \& Dawson, S. (2015). Preparing for the Digital University: A Review of the History and Current State of Distance, Blended and Online Learning. Athabasca University Press.

4. Unified Modeling Language (UML). Взято 3 http://opentechnology.ru/products/moodle

5. Youtube-канали для підтримки дистанційного навчання. Взято $3 \mathrm{http}: / / \mathrm{teach}-$ hub.com/youtube-kanaly-dlia-pidtrymky-dystantsiynoho-navchannia/

6. Бугайчук, К. (2011). Дистанційне навчання у вищих навчальних закладах МВС України: сучасні проблеми та форми впровадження. Наукові записки. Серія: Педагогіка, 1, 5763.

7. Дудіч, Г. (2020). Платформа Nearpod як ефективний інструмент синхронної та асинхронної взаємодї при дистанційному навчанні. Взято 3 https://naurok.com.ua/post/platforma-nearpod-yak-efektivniy-instrument-sinhronno-ta-asinhronnovzaemodi-pri-distanciynomu-navchanni

8. Концепція розвитку дистанційної освіти в Україні (2000). Взято 3 http://www.osvita.org.ua/distance/pravo/00.html

9. Кун, К. (2006). E-Learning - электронное обучение. Информатика и образование, 10, $16-18$.

10. Кухаренко, В. М., Березенська, С. М., \& Бугайчук, К. Л. (2016). Теорія та практика змішаного навчання. Харків: Міськдрук, НТУ ХПІ.

11. Михайлова, Н. В. (2012). Электронная обучающая среда MOODLE как средство организации асинхронной самостоятельной работы студентов вуза. (Автореф. дис. канд. наук). Оренбург.

12. Наказ Міністерства №466 від 25.04.2013. Взято 3 http://vnz.org.ua/dokumenty/spysok/3841-nakaz-ministerstva-466-vid-25042013

13. Прилуцкая, Ю. А. (2016). Активизация деятельности учащихся с помощью онлайнплатформы Nearpod. Новое слово в науке: перспективы развития : материалы VII Междунар. науч.-практ. конф. (Чебоксары, 15 янв. 2016 г.). В 2 т. Т. 1. Чебоксары: ЦНС «Интерактив плюс», 1 (7), 280-281.

14. Швецова, I. В. \& Бондаренко, В.В.(2019). Упровадження змішаного навчання (blended learning) у процесі викладання англійської мови за професійним спрямуванням. Молодий вчений, 7.2, 78-82.

15. Як використовувати YouTube у дистанційному навчанні. Взято 3 https://nus.org.ua/articles/yak-vykorystovuvaty-youtube-u-dystantsijnijnomu-navchanni/

\section{THE USE OF DIGITAL TOOLS TO PROVIDE EFFECTIVE DISTANCE AND BLENDED LEARNING IN CRISIS CONDITION}

\author{
Andrii Bespalyi \\ teacher of information technologies, specialist of the second qualification category \\ Communal institution "Pokrovsk Pedagogical Professional College" \\ Pokrovsk, Ukraine
}


Використання цифрових інструментів для забезпечення

ефективного дистанційного й змішаного навчання в кризових умовах

\author{
ORCID ID 0000-0002-3438-7106 \\ web.gynabes@gmail.com
}

\title{
Liubov Dehtiarova
}

teacher of mathematical disciplines, specialist of the first qualification category

Communal institution "Pokrovsk Pedagogical Professional College"

Pokrovsk, Ukraine

ORCID ID 0000-0001-5074-6589

lubaxa8484@gmail.com

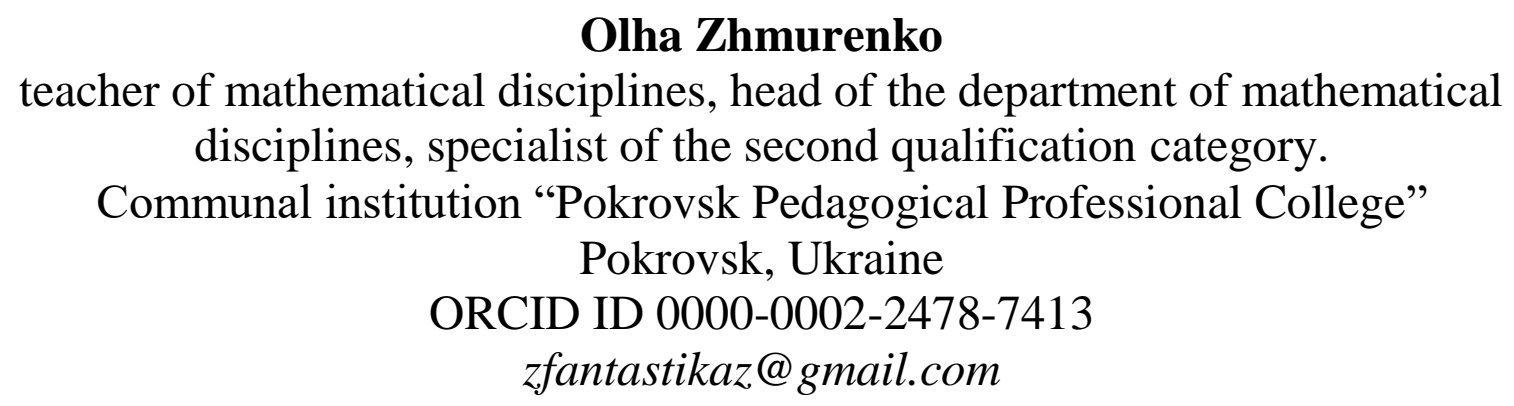

Abstract. The article is devoted to the topical problem of organizing distance and blended learning in crisis conditions: the essence of the concepts of "distance learning" and "blended learning" is revealed, digital tools for effective online learning and the benefits of distance technology are described; the roles of teachers and students in distance learning are defined.

The purpose of the article is to theoretically substantiate the essence of distance and blended learning and the effectiveness of digital tools that ensure the success of the process of such learning in a crisis.

The basic principles of distance learning are the establishment of interactive communication between the student and the teacher without ensuring their direct meeting and independent mastering of a certain array of knowledge and skills in the chosen course using certain information technologies.

Various aspects of the organization of distance and blended learning have repeatedly been the subject of research by domestic and foreign scientists (O. Andrieiev, H. Kozlakov, I. Kozubovska, V. Oliinyk, Ye. Polat, P. Stefanenko, A. Khutorskyi, B. Hershunskyi, Ye. Mashbyts, I. Pidlasyi).

Receiving educational materials, communication between the subjects of distance learning during classes are provided by the transmission of video, audio, graphic and textual information in synchronous or asynchronous modes.

During the period of distance and blended learning during the pandemic educational institutions independently chose various platforms for the implementation of the educational process. One of such platforms is the Moodle Learning Management System. In the context of the transition to the online learning format, there is a need to use tools with the functions of group chats, calls and conferences. One of the most user-friendly and easy-to-use tools is Zoom.

Key words: distance learning; blended learning; Moodle; Zoom; Nearpod; YouTube; online courses.

\section{REFERENCES}

1. Graham, C. R. (2005). Blended learning system: Definition, current trends and future direction. In: Bonk, C.J., Graham, C.R. (eds.) Handbook of Blended Learning: Global Perspectives, Local Designs, pp.3-21. Pfeiffer, San Francisco.

Професіоналізм педагога: теоретичні й методичні аспекти. Методичні матеріали до проєкту «Цифровий освітній простір: українсько-польський досвід». - Слов’янськ, 2021. 
2. Moebs, S. \& Weibelzahl, S. (2006). Towards a good mix in blended learning for small and medium sized enterprises - Outline of a Delphi Study. Proceedings of the Workshop on Blended Learning and SMEs held in conjuction with the 1stEuropean Conference on Technology Enhancing Learning. Crete, Greece, 1-6.

3. Siemens, G., Gašević, D., \& Dawson, S. (2015). Preparing for the Digital University: A Review of the History and Current State of Distance, Blended and Online Learning. Athabasca University Press.

4. Unified Modeling Language (UML). $\quad$ Retrieved from http://opentechnology.ru/products/moodle

5. Youtube Channels for Distance Learning Support. (n.d.). Retrieved from http://teachhub.com/youtube-kanaly-dlia-pidtrymky-dystantsiynoho-navchannia/

6. Buhaichuk, K. (2011). Distance Learning in Higher Educational Institutions of the Ministry of Internal Affairs of Ukraine: Modern Problems and Forms of Implementation. Pedagogy, 1, 57-63.

7. Dudich, H. (2020). Nearpod platform as an effective tool for synchronous and asynchronous interaction in distance learning. Retrieved from https://naurok.com.ua/post/platformanearpod-yak-efektivniy-instrument-sinhronno-ta-asinhronno-vzaemodi-pri-distanciynomunavchanni

8. The Concept of Development of Distance Education in Ukraine (2000). Retrieved from http://www.osvita.org.ua/distance/pravo/00.html

9. Kun, K. (2006). E-Learning - Digital Education. Informatics and Education, 10, 16-18.

10. Kukharenko, V. M., Berezenska, S. M., \& Buhaichuk, K. L. (2016). Theory and Practice of Blended Learning. Kharkiv: Miskdruk, NTU KhPI.

11. Mikhailova, N. V. (2012). Electronic learning environment MOODLE as a means of organizing asynchronous independent work of university students. (Abstract of $\mathrm{PhD}$ dissertation). Orenburg.

12. Order of the Ministry №466 dated 25.04.2013. Retrieved from http://vnz.org.ua/dokumenty/spysok/3841-nakaz-ministerstva-466-vid-25042013

13. Prilutskaya, Yu. A. (2016). Enhancing student activity with the Nearpod online platform. A new word in science: development prospects. Proceedings of VII International scientific-practical conference (Cheboksary, 15 January 2016). In 2 volumes. Vol. 1. Cheboksary, 1 (7), 280-281.

14. Shvetsova, I. V. \& Bondarenko, V. V. (2019). Introduction of blended learning in the process of teaching English in a professional field. Young Scientist, 7.2, 78-82.

15. How to Use YouTube in Distance Learning. Retrieved from https://nus.org.ua/articles/yak-vykorystovuvaty-youtube-u-dystantsijnijnomu-navchanni/

Матеріали надійшли до редакції 29.09.2021 р. 